\title{
Detection of the critical chloride threshold of carbon steel rebar in
}

\section{synthetic concrete pore solutions}

\author{
Ibrahim G. Ogunsanya a, Carolyn M. Hansson ${ }^{a^{*}}$ \\ a Mechanical and Mechatronics Engineering, University of Waterloo, Waterloo, ON, Canada N2L 3G1
}

Received: 26 October 2018 / Accepted: 10 January 2019 / Published online: 16 January 2019

(C) The Author(s) 2019. This article is published with open access and licensed under a Creative Commons Attribution 4.0 International License.

\begin{abstract}
Knowledge of the critical chloride content in concrete required to initiate corrosion of reinforcing steel is economically beneficial for the assessment and maintenance of existing structures. Also, many building codes now specify a service life of $75-100$ years for highway bridges and the critical chloride content is an essential input parameter in the models used in design of structures. There have been numerous studies aimed at determining this parameter but there is no consensus because of the many factors influencing the corrosion. The current standard methods, e.g. ASTM G109, require many weeks or months of testing and are not appropriate for testing large numbers of specimens in different conditions.

This project has demonstrated that a fairly rapid potentiodynamic polarization technique can be applied to carbon steel reinforcing bars in synthetic concrete pore solution to determine the critical value. The importance of selecting the appropriate synthetic concrete pore solution for this application is demonstrated by the different critical values obtained for different solutions.
\end{abstract}

Keywords: Carbon steel rebar; Concrete pore solution; Critical chloride threshold; Potentiodynamic polarization; Pitting potential

\section{Introduction}

Chloride-induced corrosion of reinforcing steel bars (rebar) is one of the most common causes of deterioration of reinforced structure because of marine exposure and the increasing use of de-icing and anti-icing brines employed on reinforced structures (bridges, parking lots, etc.) during the harsh winter season experienced in many countries. Chlorides diffuse through the pores of concrete structures to the reinforcement and, in sufficient quantity, they initiate active corrosion on the rebar that was initially passivated due to the high $\mathrm{pH}$ solution in the pores of the concrete. The amount of chlorides the steel can withstand before the initiation of active corrosion is generally referred to as the chloride threshold level or critical chloride level, $\mathrm{C}_{\text {crit. }}$. The knowledge of the threshold is economically beneficial for the assessment and maintenance of existing structures, so that remediation steps can be taken prior to the deterioration of structure. Also, most building codes now specify a service live of 75 100 years for highway bridges and the $C_{\text {crit }}$ is a critical input parameter in the models used in design of structures to be exposed to chloride environments.

A great amount of effort has been expended to determine the $\mathrm{C}_{\mathrm{CRIT}}$ of a reinforcement, but the values obtained vary significantly. As described by Tang et al. [1], this can be attributed to many factors. The first is the external environment: outdoor, with its variable temperature, relative humidity and precipitation, or constant laboratory conditions. The second is the test environment: simulated pore solution, mortar or concrete. The chloride threshold of bars in concrete or mortar will be influenced by cement type, any supplementary cementitious materials and/or chemical admixtures, the total cementitious content of the mix, the water-to-cementitious ratio and the age of the mortar or concrete. The third is the surface condition of the bars and the fourth is the measurement technique. For example, previous studies have employed corrosion potential monitoring, potentiostatic polarization, macrocell corrosion tests, and microcell corrosion tests. Many of these studies have been reviewed in references [2]-[4]. The decision on the methodology employed is often influenced by the time available to obtain results, but any accelerated technique has an effect on the result [5].

An additional factor is the method of introduction of the chloride. Some investigations have employed admixed chlorides in the concrete [6]-[9], while others have allowed chloride diffusion from outside of the concrete [10]-[12]. Although the former method takes less time, both methods can still take weeks to obtain results unless accelerated by other means. To reduce the time to obtain results and allow

* Corresponding author:C.M. Hansson, E-mail: chansson@uwaterloo.ca 
more control in testing, synthetic pore solutions have been widely employed as the test medium. Laboratory reagents are used to simulate the pore solutions inside of concrete and chlorides are added incrementally over time until active corrosion is observed electrochemically and/or visually. This way the chloride content at the surface of the bars is accurately known and the bars can be observed for immediate initiation of active corrosion. The disadvantage is that the same chloride concentrations exists over the whole bar, unlike the highly inhomogeneous concentrations existing in concrete structures.

In this paper, a method of determining the chloride threshold concentration was adapted from that of Williams et al. [13] who carried out tests on magnesium alloys in acid solution. It should be noted that these authors found the method to be successful for commercially pure magnesium but was less so for some magnesium alloys. This method, discussed in more detail in the next section, involves using anodic potentiodynamic polarization scans to determine the corrosion potential ( $\left.E_{\mathrm{CORR}}\right)$ and pitting potentials $\left(E_{\mathrm{PIT}}\right)$ of same grade of bars in chloride solutions. The $\mathrm{E}_{\mathrm{CORR}}$ and $\mathrm{E}_{\mathrm{PIT}}$ values are then plotted on the same graph against the increasing chloride concentration and both curves are extrapolated until they intersect. This intersection point represents the chloride concentration needed to initiate active corrosion on that particular grade of steel at its corrosion potential without any application of an anodic stimulus. It is important to mention that some authors have employed a similar method but plotting only the pitting potentials against chloride concentration without extrapolation [14], [15]. The goal in those papers was not to determine the $\mathrm{C}_{\mathrm{CRIT}}$ of the bars, but to provide a relative comparison between different bars. The overall objective of the current work is to demonstrate this relatively rapid method of determining the threshold can be used for reinforcing bars in simulated concrete pore solution.

Many authors have tested rebar in saturated calcium hydroxide $\mathrm{pH} \sim 12.6$ and some have used a synthetic pore solution based on $\mathrm{KOH}, \mathrm{NaOH}$ and $\mathrm{Ca}(\mathrm{OH})_{2}$ with $\mathrm{pH} \sim 13.6$. Clearly, however, the pore solution composition must be representative of that in the specific concrete mix of interest. A recent study of the influence of the water/cementitious materials $(\mathrm{w} / \mathrm{cm})$ ratio and supplementary cementitious materials (SCM) content on the pore solution composition [16] has shown that, with increasing admixed chloride, there is an increased sulphate content in the pore solution. Yet only few authors have incorporated sulphate in their synthetic pore solution testing [17]-[20], and only at the beginning of their test without further additions with increasing chlorides. Therefore, the second objective of the current work was to employ the anodic potentiodynamic polarization method to determine the chloride threshold of reinforcing bars rebar in different "pore solutions".

\section{Materials and methods}

Carbon steel reinforcing bars (rebar), with composition shown in Table 1 were cut to $127 \mathrm{~mm}$ (5.0 in) in length, drilled on one end, soldered with a solid copper wire and lacquer was applied to both ends to allow an exposed length of $76 \mathrm{~mm}$ (3.0 in) The specimens were cleaned with alcohol to remove contaminations from handling. The specimens were then placed in their respective testing solutions in a three-probe electrochemical cell shown in Figure 1 . The reference electrode was a saturated calomel electrode (SCE) and the cylindrical counter electrode was a mixed metal oxide coated titanium mesh.

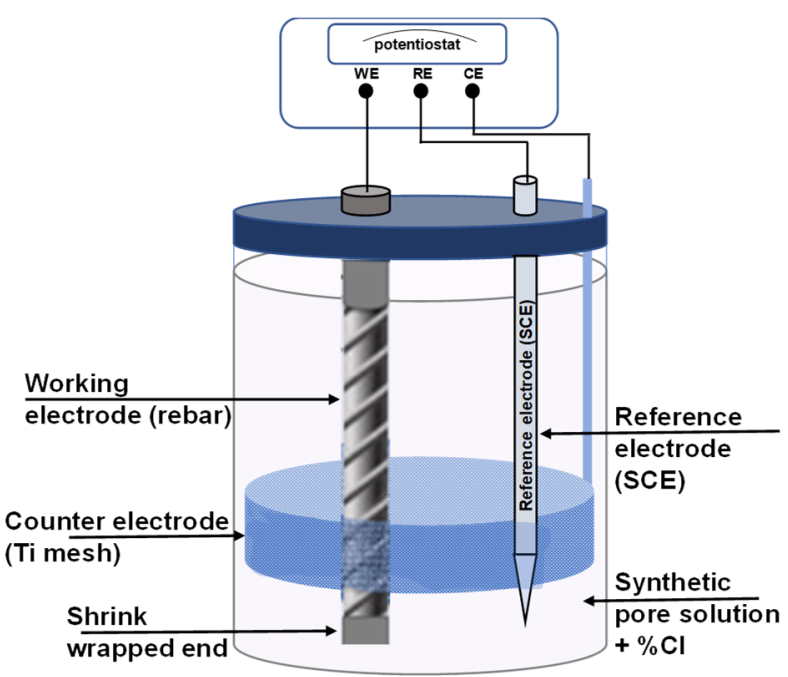

Figure 1. Three-probe electrochemical cell with a mixed metal-oxide titanium mesh counter electrode and a saturated calomel reference electrode (SCE).

Three testing solutions were employed in total as presented in Table 2. One solution (designated as PS+S) was based on the composition of the expressed solutions from a specific $75 \%$ Portland cement $/ 25 \%$ ground granulated blast furnace slag mixture with a w/cm of 0.40 and different $\mathrm{NaCl}$ additions. The second solution (designated as PS) was based on the same solution but omitted the sulphates and the third solution was saturated $\mathrm{Ca}(\mathrm{OH})_{2}$ solution (designated as $\mathrm{CH}$ ). The percentages shown in Table 2 correspond to the amount of analytical reagent grade compound added to deionized water to make $100 \mathrm{~mL}$ of solution. Excess solid $\mathrm{Ca}(\mathrm{OH})_{2}$ was present at all times in all solutions during testing. Each solution was stirred to ensure complete dissolution of all the salts and $\mathrm{pH}$ measurements were taken afterwards.

In the work of [16], increasing sulphates were found with increasing chlorides in the pore solutions expressed from cement pastes with increasing admixed chlorides after 28 days as shown in Figure 2. The equivalent amount of sulphate added at each chloride addition is shown Table 3.

Table 1. The mill certificate composition of tested carbon steel rebar.

\begin{tabular}{|c|c|c|c|c|c|c|c|c|c|c|c|c|c|}
\hline & Comp & tion (w & & & & & & & & & & & \\
\hline Constituent & C & $\mathrm{Mn}$ & $\mathrm{P}$ & $S$ & $\mathrm{Si}$ & $\mathrm{Cu}$ & $\mathrm{Ni}$ & $\mathrm{Cr}$ & Mo & V & $\mathrm{N}$ & $\mathrm{Sn}$ & $\mathrm{Fe}$ \\
\hline Amount & 0.210 & 1.310 & 0.008 & 0.018 & 0.180 & 0.260 & 0.060 & 0.090 & 0.013 & 0.050 & 0.010 & 0.021 & balance \\
\hline
\end{tabular}


Table 2. Testing solutions.

\begin{tabular}{|l|l|l|l|l|l|}
\hline \multirow{2}{*}{$\begin{array}{l}\text { Testing } \\
\text { solution } \\
\text { (denotations) }\end{array}$} & \multicolumn{2}{|l|}{ Composition (\%) } & $\mathrm{pH}$ \\
\cline { 2 - 6 } & $\mathrm{Ca}(\mathrm{OH})_{2}$ & $\mathrm{KOH}$ & $\mathrm{NaOH}$ & $\mathrm{CaSO}_{4} \cdot 2 \mathrm{H}_{2} \mathrm{O}$ & \\
\hline $\begin{array}{l}\text { Calcium } \\
\text { hydroxide } \\
(\mathrm{CH})\end{array}$ & Saturated & 2.68 & 0.51 & & $\sim 12.5$ \\
\hline $\begin{array}{l}\text { Pore solution } \\
\text { (PS) }\end{array}$ & 0.01 & 2.68 & 0.51 & 0.23 & $\sim 13.6$ \\
\hline $\begin{array}{l}\text { Pore solution } \\
\text { plus sulphate } \\
\text { (PS+S) }\end{array}$ & 0.01 & & 13.5 \\
\hline
\end{tabular}

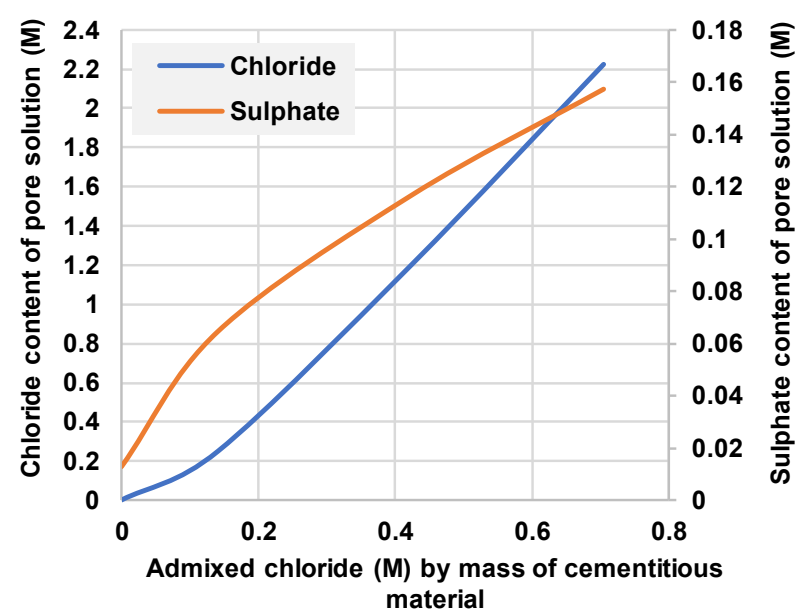

Figure 2. The chloride and sulphate contents of the pore solution expressed from $75 \%$ Portland cement $/ 25 \%$ slag pastes $0.4 \mathrm{w} / \mathrm{cm}$ ratio and the admixed chlorides, as $\mathrm{NaCl}$, in the 28 days old paste. Adapted from [16].

The bars were allowed to passivate in their respective testing solutions for two weeks before any chloride and sulphate was added and before any testing was carried out. After the bars have reached full passivation (determined by a non-varying corrosion potential), chlorides and sulphates (in the PS+S solution) were added as $\mathrm{NaCl}$ and $\mathrm{CaSO}_{4} \cdot 2 \mathrm{H}_{2} \mathrm{O}$ and the solutions were stirred for one minute with a magnetic stirrer to completely dissolve the solutes. After the corrosion potential of the steel bars stabilized, indicating equilibrium had been reached, an anodic potentiodynamic polarization test was performed on each bar in its respective solution with a scan rate of $0.01 \mathrm{mV} / \mathrm{s}$ as suggested by [5] using the BioLogic potentiostat Model VSP. Each bar was scanned from its corrosion potential in the anodic direction to $0.5 \mathrm{~V}_{\mathrm{SCE}}$ (or to the current limit of $5 \mathrm{~mA}$ ) and, if the bar did not display any pitting potential, reversed in the cathodic direction to observe any hysteresis loop. The values of the corrosion potential, $E_{C O R R}$, pitting potential, $E_{P I T}$, were noted. The $E_{C O R R}$ and $E_{P I T}$ values from each polarization curve were then plotted against the chloride content of the solution.

\section{Results}

Figure 3 shows examples of the corrosion potentials of the bars allowed to passivate in their different testing solutions without chlorides. It can be seen that the $\mathrm{E}_{\mathrm{CORR}}$ values were relatively similar after $200 \mathrm{hrs}$, indicating that the bars had reached equilibrium with the testing solution. After the addition of chlorides, a longer wait time before the application of anodic polarization was attempted but, due to the inhomogeneity of the mill scale on the rebar, the potential values of some bars in the solutions with higher chloride contents, became more negative after $\sim 30$ mins and then remained approximately constant thereafter. This suggests initiation of pitting corrosion and repassivation on some regions on those bars. When anodic polarization was applied to these bars, some showed curves with defined pitting potentials, while others exhibited general corrosion behaviour. Therefore, for consistency, 30 minutes "wait time" was chosen for all bars in solution at all chloride concentrations.

Table 3. Chlorides and sulphate additions to testing solutions

\begin{tabular}{|c|c|c|c|c|c|c|c|c|}
\hline \multicolumn{9}{|c|}{ Chloride and sulphate content as molar ion in solution and as mass $\%$ of compound in solution } \\
\hline \multicolumn{9}{|l|}{ In $\mathrm{CH}$ solution } \\
\hline $\mathrm{M} \mathrm{Cl}-(\mathrm{NaCl}, \%)$ & $\begin{array}{l}0.028 \\
(0.17) \\
\end{array}$ & $\begin{array}{l}0.056 \\
(0.34) \\
\end{array}$ & $\begin{array}{l}0.085 \\
(0.51) \\
\end{array}$ & $\begin{array}{l}0.113 \\
(0.68) \\
\end{array}$ & $\begin{array}{l}0.141 \\
(0.85)\end{array}$ & $\begin{array}{l}0.310 \\
(1.87) \\
\end{array}$ & $\begin{array}{l}0.338 \\
(2.04) \\
\end{array}$ & $\begin{array}{l}0.366 \\
(2.21)\end{array}$ \\
\hline \multicolumn{9}{|l|}{ In PS solutions } \\
\hline $\mathrm{M} \mathrm{Cl}-(\mathrm{NaCl}, \%)$ & $\begin{array}{l}0.451 \\
(2.72) \\
\end{array}$ & $\begin{array}{l}0.507 \\
(3.06)\end{array}$ & $\begin{array}{l}0.563 \\
(3.40) \\
\end{array}$ & $\begin{array}{l}0.620 \\
(3.74) \\
\end{array}$ & & & & \\
\hline \multicolumn{9}{|l|}{ In PS + S Solution } \\
\hline $\mathrm{M} \mathrm{Cl}-(\mathrm{NaCl}, \%)$ & $\begin{array}{l}0.451 \\
(2.72) \\
\end{array}$ & $\begin{array}{l}0.507 \\
(3.06) \\
\end{array}$ & $\begin{array}{l}0.535 \\
(3.23) \\
\end{array}$ & $\begin{array}{l}0.563 \\
(3.40) \\
\end{array}$ & $\begin{array}{l}0.620 \\
(3.74) \\
\end{array}$ & & & \\
\hline $\mathrm{M} \mathrm{SO}_{4}{ }^{2-}\left(\mathrm{CaSO}_{4} \cdot 2 \mathrm{H}_{2} \mathrm{O}, \%\right)$ & $\begin{array}{l}0.080 \\
(1.44)\end{array}$ & $\begin{array}{l}0.084 \\
(1.52)\end{array}$ & $\begin{array}{l}0.086 \\
(1.56)\end{array}$ & $\begin{array}{l}0.089 \\
(1.59)\end{array}$ & $\begin{array}{l}0.091 \\
(1.63)\end{array}$ & & & \\
\hline
\end{tabular}




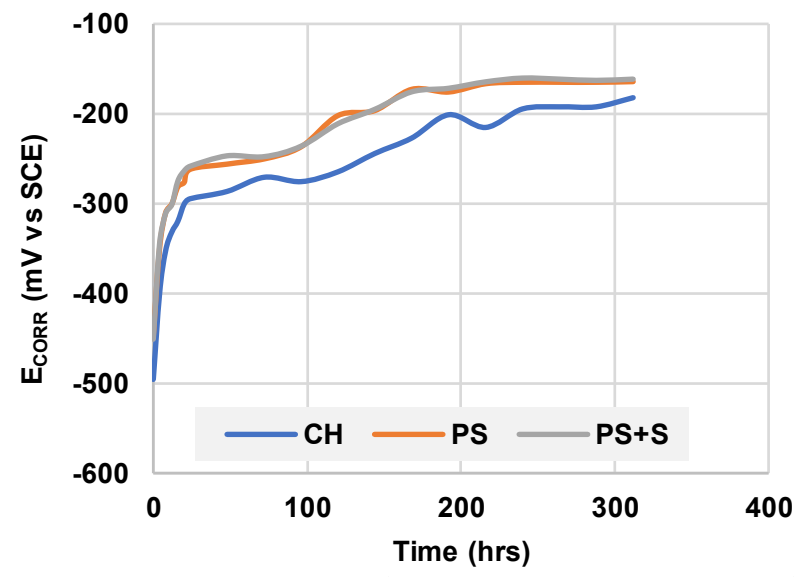

Figure 3. Corrosion potentials of bars in solution over the course of passivation.

An important point to mention is the success rate of obtaining pitting potentials from the anodic scans of these carbon steel bars. Although plots with data point of three replicates of bars tested in each solution are presented in the figures below, about five specimens were tested to obtain each data point. Some results were discarded because the tested bars showed crevice corrosion underneath the lacquer in addition to exhibiting pitting corrosion in the exposed area, as shown in Figure 4. As also evident in Figure 4, there was generally good bonding between the bar and the lacquer, although crevice corrosion did occur in some cases. A few other potentiodynamic scans exhibited the behaviour of general corrosion with no clear onset of pitting and, examination of their pre-test photographs revealed a mill scale that was characterised with several pits along the length of the specimen, Figure 5 . Again, such results were discarded. In general, as observed by [13], the success rate of obtaining $\mathrm{C}_{\mathrm{CRIT}}$ results using the potentiodynamic scans is dependent on the type and/or surface condition of the material. Particularly in this work, it was mostly due to the nature of the mill scale (a complex iron oxide layer) that forms on these bars during the hot rolling process of their steel fabrication which affects the behaviour of the steel in solution. The variation in mill scale between manufacturers, the inhomogeneity along the length of a specimen to be tested, the non-uniformity in thickness and microstructure, and the influence of these factors on electrochemical test results in the presence of chlorides is well documented in the work of Ghods et al. [21].

The initial tests in the PS and PS+S solutions were in the same chloride range as those in the $\mathrm{CH}$ solution, that is, from 0.014 to $0.423 \mathrm{M}$ by mass of solution in $0.014 \mathrm{M}$ increments. However, all of the curves indicated passive behaviour, with the return sweep at lower current densities than exhibited in the forward sweep, as shown for the PS solution with 0.423 $\mathrm{M} \mathrm{Cl}$ in Figure 6. In contrast, it was difficult to obtain a defined pitting onset from the polarization curves obtained from specimens in PS solution with chloride contents greater than $0.62 \mathrm{M}$ by mass of solution because of the high rate of corrosion.

Figures $7-9$ shows the polarization curves obtained from specimens tested in the $\mathrm{CH}, \mathrm{PS}$ and $\mathrm{PS}+\mathrm{S}$ solutions with chlorides respectively. The potential value before the sharp increase in current is known as the breakdown or pitting potential $\left(E_{\mathrm{PIT}}\right)$. A general observation is the more negative $E_{\text {CORR }}$ values and decreasing passivity range with increasing chlorides, as found in other work [14], [15], [22], [23]. A decreasing $E_{\text {CORR }}$ value of carbon steel rebar has been observed in both tests carried out in chloride-contaminated pore solution [14], [22], and in cracked concrete exposed to chlorides [23]-[25]. This behaviour is mainly influenced by the surface finish of the bar, particularly the mill scale. At the higher chloride levels, the passive current density increased gradually up to the pitting potential in Figures 7 - 9.

The polarization curves from bars in the PS and PS $+S$ solutions are similar, but the presence of sulphates results in more anodic $\mathrm{E}_{\mathrm{PIT}}$ values. The passive current densities of bars in these solutions are similar and lower than those in the $\mathrm{CH}$ solution, which is consistent with past findings [26], [27]. A current density value with the order of magnitude of $10^{-3}$ $\mathrm{A} / \mathrm{m}^{2}$ is typically considered passive [28].

\section{Before and after pitting corrosion}

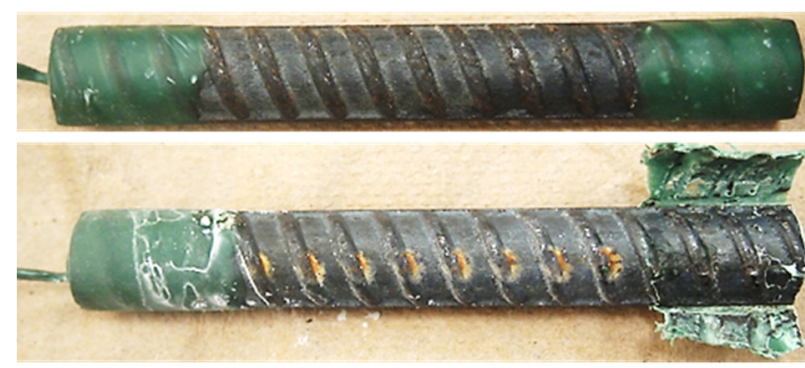

\section{Bars discarded due to crevice corrosion}

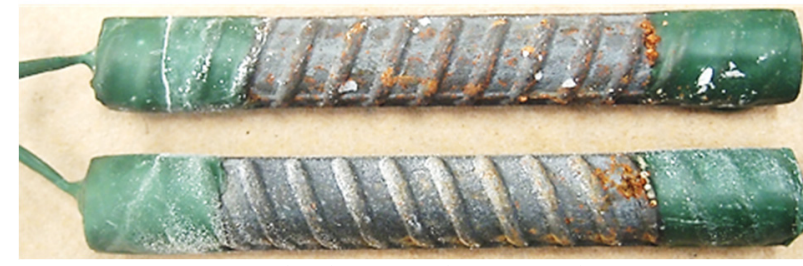

Figure 4. An example of before and after testing for pitting potential is shown at the top of the figure. The after tested bar showed clear pitting corrosion underneath the side rib with no crevice corrosion underneath the lacquer. Bars at the bottom, tested for similar purpose but showed crevice corrosion, albeit pitting corrosion in some case, were discarded. 

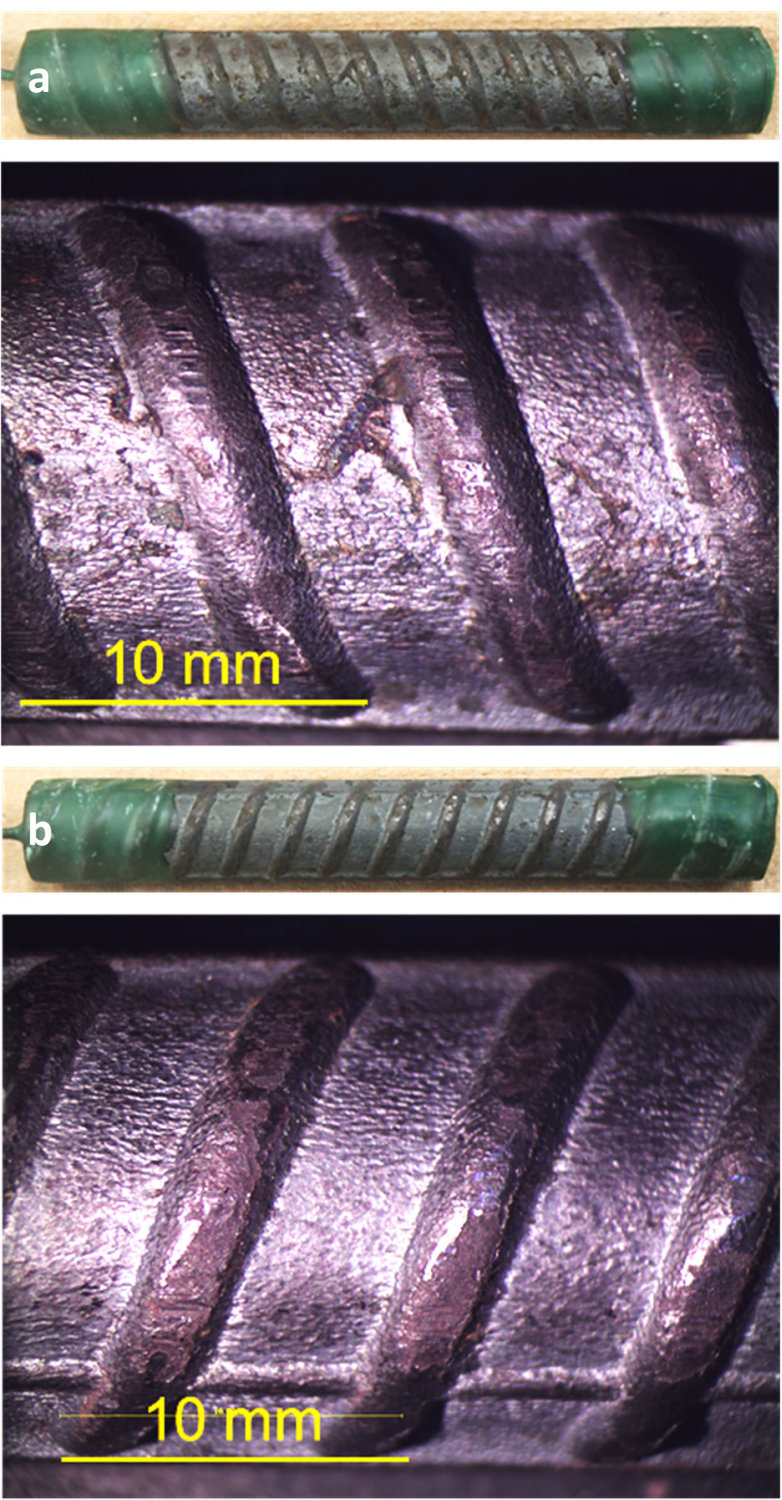

Figure 5. An example of as-received bars (a and b) prepared for testing (top photos) and their micrographs showing the condition of their mill scales (bottom photos). The bar on image a shows a rough mill scale with several pits than those on the image $b$, which in turn resulted in general corrosion when tested.

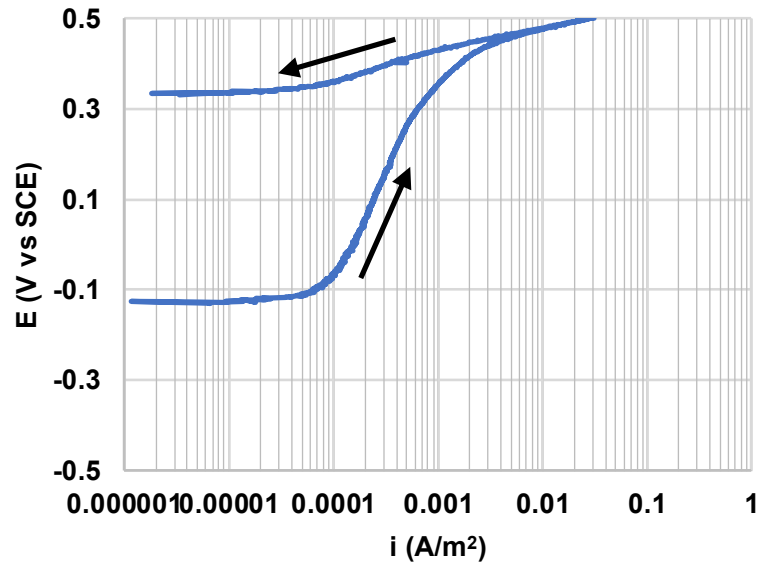

Figure 6. Polarization curves of specimens in PS solution with $1.5 \% \mathrm{Cl}-$ by mass of solution showing no pitting potentials.

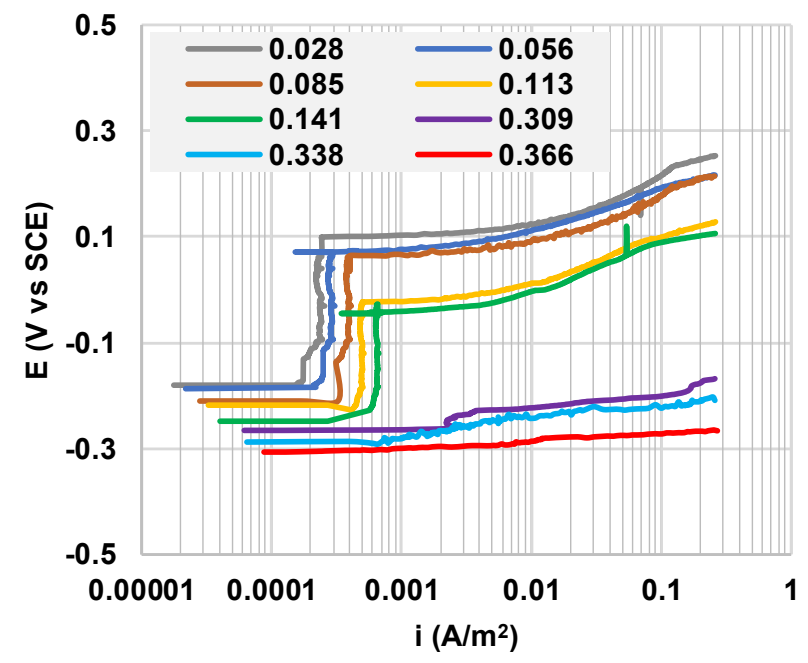

Figure 7. Polarization curves of specimens in $\mathrm{CH}$ solution with chlorides from 0.028 to $0.366 \mathrm{M}$ by mass of solution showing pitting corrosion.

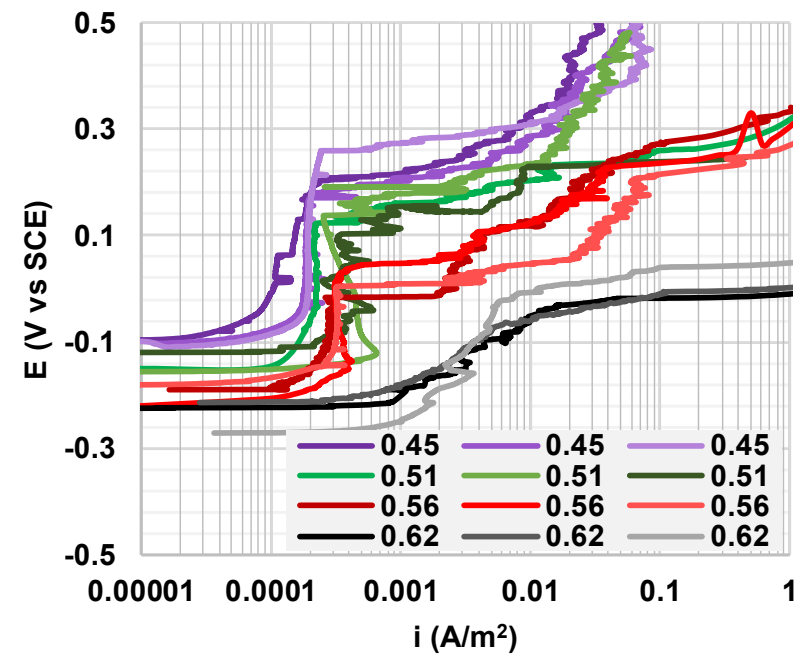

Figure 8. Polarization curves of specimens in PS solution with chlorides from 0.45 to $0.62 \mathrm{M}$ by mass of solution showing pitting corrosion.

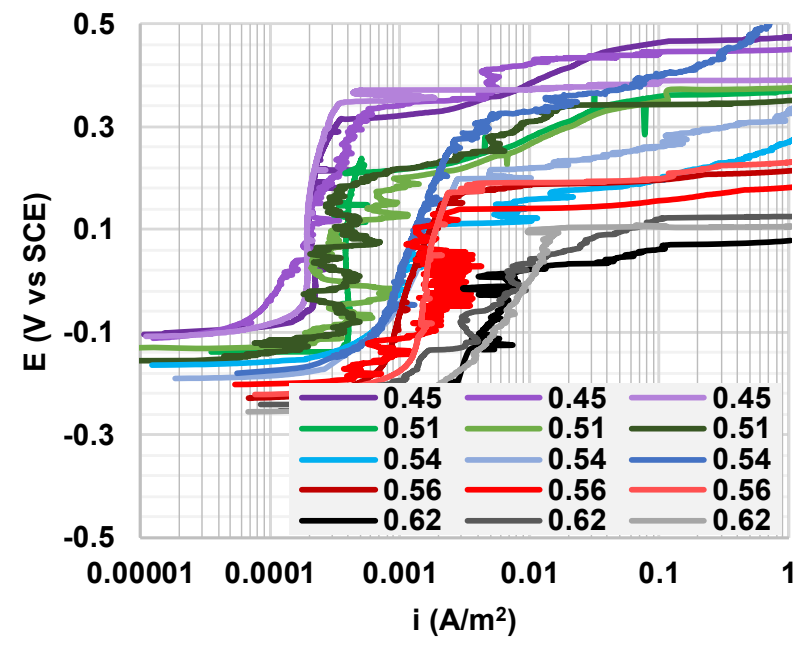

Figure 9. Polarization curves of specimens in $P S+S$ solution with chlorides from 0.45 to $0.62 \mathrm{M}$ by mass of solution showing pitting corrosion. 


\section{Discussion}

Figures 10 to 12 show the potential versus chloride plots that summarise the passivity and pitting behaviour and, allows prediction of the chloride thresholds of carbon steel rebar in the $\mathrm{CH}, \mathrm{PS}$ and $\mathrm{PS}+\mathrm{S}$ solutions, respectively. Each figure shows the data for the corrosion potentials $\left(E_{\text {CORR }}\right)$ and pitting potentials $\left(E_{\mathrm{PIT}}\right)$ obtained from the polarization curves above, as a function of the chloride content of the solution. Trendlines for the $\mathrm{E}_{\mathrm{CORR}}$ and $\mathrm{E}_{\mathrm{PIT}}$ data are extrapolated to their intersection point which, as described above, represents the chloride content of the solution at which corrosion is initiated without the application of an external stimulus, that is the chloride threshold value, $\mathrm{C}_{\mathrm{CRIT}}$.

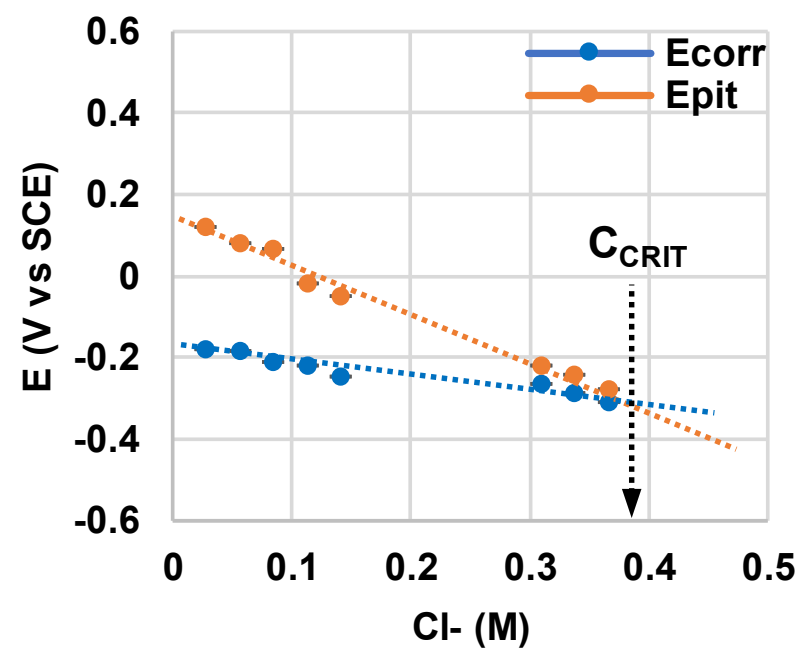

Figure 10. ECORR and EPIT versus chlorides extrapolated to predict the chloride threshold of carbon steel in $\mathrm{CH}$ solution. Note the difference in scale from Figures 10 and 11.

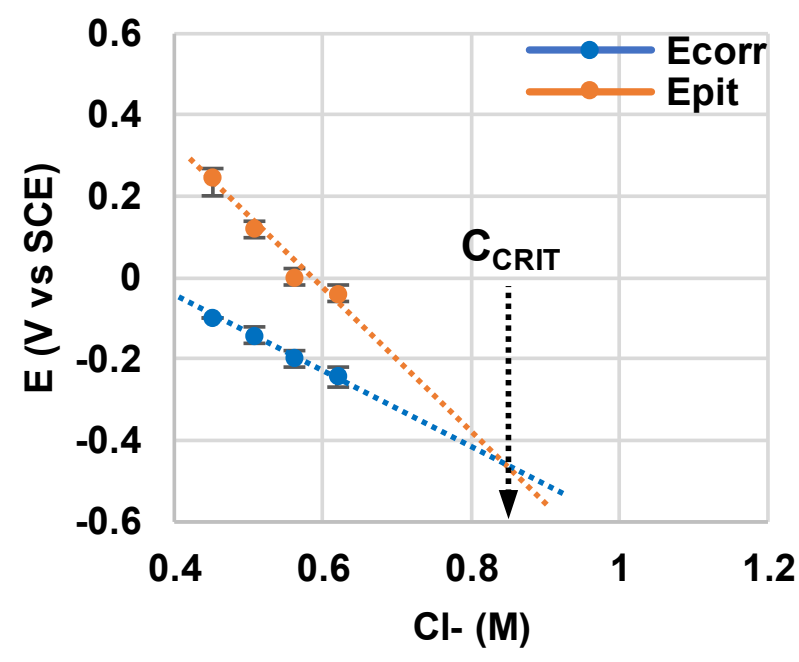

Figure 11. The average and maximum and minimum of three replicates of ECORR and EPIT versus chlorides extrapolated to predict the chloride threshold of carbon steel in PS solution.

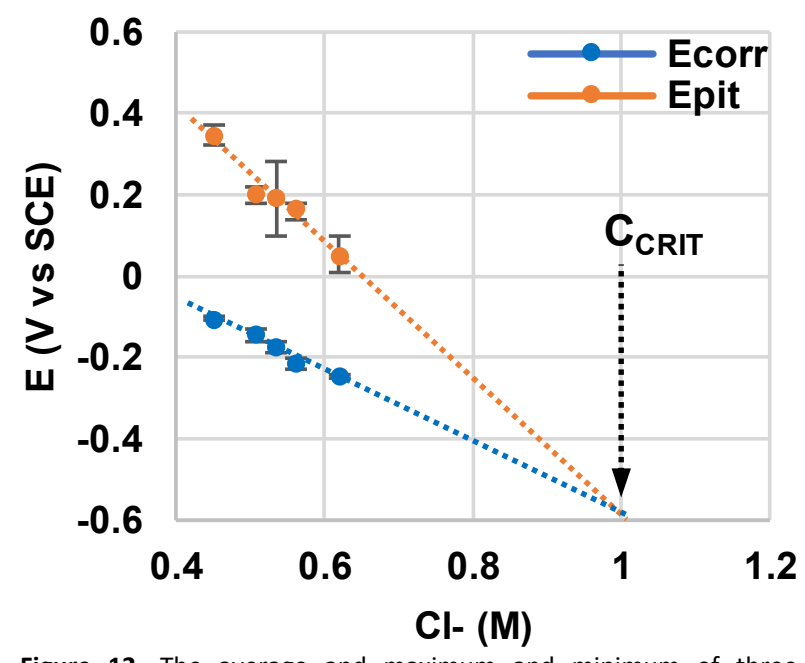

Figure 12. The average and maximum and minimum of three replicates of ECORR and EPIT versus chlorides extrapolated to predict the chloride threshold of carbon steel in PS+S solution.

The critical chloride threshold obtained for bars in the $\mathrm{CH}, \mathrm{PS}$ and PS+S solutions were found to be approximately $0.38 \mathrm{M}$, $0.85 \mathrm{M}$ and $1 \mathrm{M}$ by mass of testing solution respectively. Using the data for the expressed pore solutions shown in Figure 2, these values translate to approximately $0.17 \mathrm{M}, 0.34 \mathrm{M}$ and $0.37 \mathrm{M} \mathrm{Cl}$ - by mass of cementitious material in cement or concrete. The $\mathrm{C}_{\mathrm{CRIT}}$ values of bars in $\mathrm{CH}$ and PS solutions fall within the range $(0.07-0.56 \mathrm{M}$ by mass of cementitious) of those observed by [8], [9], [26], [29]-[34] using different methodology. No comparison for $\mathrm{C}_{\mathrm{CRIT}}$ value could be made for bars in the PS+S solution because there does not appear to be any literature using similar solutions. However, Leckie and Uhlig [35] showed in their work in the 60's that sulphate increment in acid solution improved the pitting resistance of stainless steel bar.

The $\mathrm{pH}$ of the solutions was determined only at the start of the tests and it is clear that the concept of a constant $\mathrm{Cl} / \mathrm{OH}$ ratio does not hold for these solutions, based on the initial $\mathrm{pH}$ values. This observation is in agreement with the results of a parallel study of expressed pore solution from cement pastes with admixed $\mathrm{NaCl}$ for which the $\mathrm{pH}$ varied with chloride content between 13.2 and 13.5 and molar ratios of $\mathrm{Cl} / \mathrm{OH}$ in solution varied from 0.077 to 1.44 .

To confirm that the $\mathrm{C}_{\mathrm{CRIT}}$ values obtained in this work can initiate active corrosion on the carbon steel rebar tested in all three solutions, a test was carried out to monitor the corrosion potentials of bars in solution before and after the addition of chlorides and sulphates. 


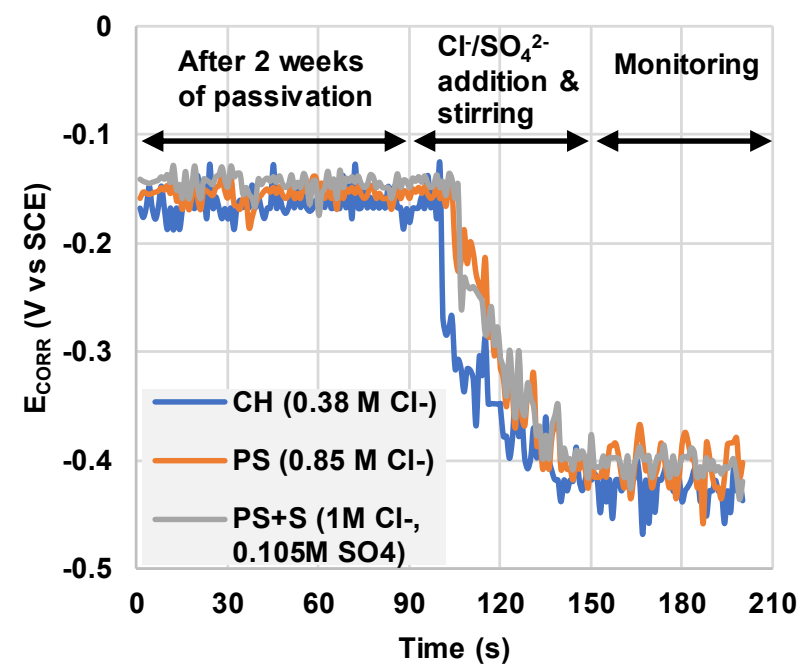

Figure 13. Corrosion potentials of bars in each of the three solutions containing the "critical chloride concentration" for each.

Similar to other bars being tested, these bars were passivated for 2 weeks in their respective containers and then placed on a stirrer. Each cell was hooked up to a potentiostat to monitor the $\mathrm{E}_{\mathrm{CORR}}$ values for 90 seconds before the addition of salt. After 90 seconds, salts were added and, each solution was stirred using a magnetic stirrer for a minute. The $\mathrm{E}_{\text {CORR }}$ values were then monitored to observe any subsequent changes and the data are shown in Figure 13.

It is important to emphasize that the PS and PS+S solutions employed in this work were prepared based on composition of expressed solution from a particular cementitious mixture type $(75 \%$ Portland cement/25\% ground granulated blast furnace slag mixture with a w/cm of 0.40 ) at $0 \%$ admixed chloride. This same base mixture was prepared for each chloride (and sulphate) level.

On the question of applicability of these results to chlorides penetrating into concrete from the environment, it is generally accepted that it is the highly concentrated ionic solution in the pores of the concrete, not the solid phases, which is responsible for the passivation of the steel in the noncontaminated concrete, and for the corrosion once the concrete is contaminated. Ideally, therefore, one should determine the composition of the pore solution in the close vicinity of the rebar. Unfortunately, this is not feasible because there is insufficient cementitious material to be able to express and analyse the pore solution. Moreover, as discussed in detail by Tang et. al [1], the chloride content in concrete exposed to saline conditions is highly inhomogeneous, both through the depth of the concrete cover and along the length of the interface between the concrete and the rebar. Determining the critical chloride concentration of structures in service is fraught with even more difficulties including: selection of the most appropriate locations for sampling; the lack of knowledge of the corrosion initiation time and, hence the chloride concentration at that time and the inclusion of possible carbonation effects [36].
The sulphates in cement paste are known to be concentrated in the aluminate phases, ettringite and monosulphate and, therefore, it may be assumed that these phases are the source of the sulphates found in the pore solution [37]. Friedel and Kuzel [38] salts are major solid phases formed during chloride binding and their formation process requires ion exchange of the sulphates in the aluminate phases into the pore solution [39]. The formation of these salts has been found to occur for both admixed and ingressed chlorides [36]. Therefore, this work considers the PS+S solution close to the scenario found in field concrete and, therefore, it is deemed important to determine the effect of the sulphate release on the corrosion resistance of the embedded rebar.

\section{Potential applications and developments}

The test procedure is currently being applied to five different stainless steel rebar grades in a synthetic pore solution of the same composition as the PS+S used in the current tests, in order to assess their relative resistance to chloride attack. It is also being used to evaluate the relative effects of different chloride salts, namely $\mathrm{CaCl}_{2}, \mathrm{MgCl}_{2}$ in comparison to the commonly used $\mathrm{NaCl}$.

Future developments of the test method will focus on the critical chloride levels of steel in mortar. Rebar will be cast in cylindrical mortar specimens with a small cover and, after curing, will be exposed to chlorides for different time periods prior to the cyclic potentiostatic polarization. Details of the procedure require "trial and error" determination. If successful, this procedure will lend itself to assessment of the effect of mortar mixture design, rebar surface finish, environmental conditions etc. A comparison of the results of these tests with those presented here will also clarify the relevance of testing corrosion in synthetic pore solution.

\section{Summary and Conclusions}

- The potentiodynamic polarization scan method of determining chloride threshold level was successful in determining the $\mathrm{C}_{\mathrm{CRIT}}$ of carbon steel rebar in three different synthetic pore solutions. Obtaining results through this method is shown to be dependent on the surface condition of the carbon steel rebar. On average, five specimens were tested before three replicates in each data point in Figures 11 and 12 were obtained. Furthermore, at chloride concentrations close to the $\mathrm{C}_{\mathrm{CRIT}}$ value of the bar in solution, it was difficult to obtain a polarization curve with defined pitting onset.

- The threshold level determined by this method increased from $0.38 \mathrm{M}$ in the $\mathrm{CH}$ solution to $1 \mathrm{M}$ in the synthetic pore solution containing sulphates. Using the data in Figure 2 obtained from expressed pore solution at 28 days of slag cementitious mix with admixed chloride, the latter value would be equivalent to $0.37 \mathrm{M}$ by mass of cementitious materials in cement paste, mortar or concrete with the same cementitious mix.

- Corrosion potential monitoring test confirms that the $\mathrm{C}_{\mathrm{CRT}}$ values obtained in this work for each of the three 
solutions is sufficient to initiate active corrosion on the carbon steel rebar tested.

- The addition of sulphate to pore solution at levels corresponding to those measured in expressed pore solution increased the $\mathrm{C}_{\mathrm{CRIT}}$ of bars from $0.85 \mathrm{M}$ to $1.00 \mathrm{M}$ $\mathrm{Cl}^{-}$by mass of pore solution. This is approximately $18 \%$ and equivalent to $0.03 \mathrm{M}$ by mass of cementitious material.

- Sulphate increments, which were shown to improve the pitting resistance in acid solution in a past research [35], are also shown here to have positive impact on the $\mathrm{C}_{\mathrm{CRIT}}$ value obtained from the extrapolation of $E_{\text {CORR }}$ and $E_{P I T}$ obtained from the potentiodynamic polarization curves of bars tested in alkaline solution.

- As mentioned above, there are numerous factors influencing the critical chloride concentration for rebar in concrete, including environmental conditions, rebar surface state, concrete mixture design and chloride cation type. However, by replicating the pore solution composition of the specific concrete of interest, and using the applicable chloride salt, this potentiodynamic scan method can be used to determine the influence of the last two factors.

\section{Acknowledgments}

The authors appreciate the funding and support provided for this project by the Natural Sciences and Engineering Research Council of Canada.

\section{References}

[1] L. Tang, J. M. Frederiksen, U. M. Angst, R. Polder, M. C. Alonso, B. Elsener, D. Hooton, J. Pacheco, Experiences from RILEM TC 235-CTC in recommending a test method for chloride threshold values in concrete, RILEM Tech Lett (2018) 3: 25-31. https://doi.org/10.21809/rilemtechlett.2018.55

[2] G. K. Glass, N. R. Buenfeld, The presentation of the chloride threshold level for corrosion of steel in concrete, Corros Sci (1997) 39: 10011013, 1997. https://doi.org/10.1016/S0010-938X(97)00009-7

[3] C. Alonso, C. Andrade, M. Castellote, P. Castro, Chloride threshold values to depassivate reinforcing bars embedded in a standardized OPC mortar, Cem Concr Res (2000) 30: 1047-1055. https://doi.org/10.1016/S0008-8846(00)00265-9

[4] U. Angst, B. Elsener, C. K. Larsen, $\varnothing$. Vennesland, Critical chloride content in reinforced concrete - A review, Cem Concr Res (2009) 39: 1122-1138. https://doi.org/10.1016/i.cemconres.2009.08.006

[5] A. Poursaee, C. M. Hansson, Potential pitfalls in assessing chlorideinduced corrosion of steel in concrete, Cem Concr Res (2009) 39: 391-400, 2009. https://doi.org/10.1016/j.cemconres.2009.01.015

[6] [6] B. B. Hope, A. K. C. Ip, Chloride corrosion threshold in concrete, ACI Mater J (1987): 306-314.

[7] K. W. J. Treadaway, R. N. Cox, B. L. Brown, Durability of corrosion resisting steels in concrete, Proc Inst Civ Eng Part 1 (1989) 86: 305331.

[8] W. Morris, A. Vico, M. Vazquez, Chloride induced corrosion of reinforcing steel evaluated by concrete resistivity measurements, Electrochim Acta (2004) 49: 4447-4453. https://doi.org/10.1016/j.electacta.2004.05.001

[9] W. Morris, A. Vico, M. Vazquez, S. R. De Sanchez, Corrosion of reinforcing steel evaluated by means of concrete resistivity measurements, Corros Sci, (2002) 44: 81-99. https://doi.org/10.1016/S0010-938X(01)00033-6

[10] M. D. A. Thomas, Field studies of fly ash concrete structures containing reactive aggregates, Mag Concr Res (1996) 48: 265-279. https://doi.org/10.1680/macr.1996.48.177.265
[11] M. D. A. Thomas, P. B. Bamforth, Modelling chloride diffusion in concrete effect of fly ash and slag, Cem Concr Res (1999) 29: 487495. https://doi.org/10.1016/S0008-8846(98)00192-6

[12] P. Sandberg, Studies of chloride binding in concrete exposed in a marine environment, Cem Concr Res (1999) 29: 473-477. https://doi.org/10.1016/S0008-8846(98)00191-4

[13] G. Williams, H. A. L. Dafydd, H. N. Mcmurray, Chloride Ion Concentration Effects on Passivity Breakdown in Magnesium, 224th ECS Meet (2017) 73: 2013.

[14] P. Ghods, O. B. Isgor, G. A. McRae, G. P. Gu, Electrochemical investigation of chloride-induced depassivation of black steel rebar under simulated service conditions, Corros Sci (2010) 52: 1649-1659. https://doi.org/10.1016/i.corsci.2010.02.016

[15] B. Elsener, D. Addari, S. Coray, A. Rossi, Stainless steel reinforcing bars - Reason for their high pitting corrosion resistance, Mater Corros (2011) 62: 111-119. https://doi.org/10.1002/maco.201005826

[16] C. B. Van Niejenhuis, I. G. Ogunsanya, C. M. Hansson, Analysis of pore solution expressed from Portland cement pastes with and without supplementary cementitious materials and admixed chlorides, $\mathrm{ACl}$ Mater J, submitted 2018.

[17] C. M. Hansson, T. D. Marcotte, Corrosion products that form on steel within cement paste, Mater Struct (2007) 40: 325-340. https://doi.org/10.1617/s11527-006-9170-4

[18] M. J. Hunt, C. M. Hansson, The influence of cations in anti-icing brines on the corrosion of reinforcing steel in synthetic concrete pore solution, Corrosion (2015) 71: 749-757. https://doi.org/10.5006/1328

[19] Z. Q. Tan, C. M. Hansson, Effect of surface condition on the initial corrosion of galvanized reinforcing steel embedded in concrete, Corros Sci (2008) 50: 2512-2522. https://doi.org/10.1016/j.corsci.2008.06.035

[20] J. Williamson, O. B. Isgor, The effect of simulated concrete pore solution composition and chlorides on the electronic properties of passive films on carbon steel rebar, Corros Sci (2016) 106: 82-95. https://doi.org/10.1016/i.corsci.2016.01.027

[21] P. Ghods, O. B. Isgor, G. A. McRae, J. Li, G. P. Gu, Microscopic investigation of mill scale and its proposed effect on the variability of chloride-induced depassivation of carbon steel rebar, Corros Sci (2011) 53: 946-954. https://doi.org/10.1016/j.corsci.2010.11.025

[22] A. Poursaee, Corrosion of steel bars in saturated $\mathrm{Ca}(\mathrm{OH}) 2$ and concrete pore solution, Concr Res Lett (2010) 1: 90-97.

[23] A. Poursaee, Potentiostatic transient technique, a simple approach to estimate the corrosion current density and Stern-Geary constant of reinforcing steel in concrete, Cem Concr Res (2010) 40: 1451-1458. https://doi.org/10.1016/j.cemconres.2010.04.006

[24] C. B. Van Niejenhuis, S. Walbridge, C. M. Hansson, The performance of austenitic and duplex stainless steels in cracked concrete exposed to concentrated chloride brine, J Mater Sci (2010) 51: 362-374. https://doi.org/10.1007/s10853-015-9387-0

[25] I. G. Ogunsanya, C. M. Hansson, The influence of coating thickness and compostion on corrosion propagation rates of galvanized rebar in cracked concrete, Waterloo, CJ-1612-OA-2370, 2016.

[26] L. T. Mammoliti, L. C. Brown, C. M. Hansson, B. B. Hope, The influence of surface finish of reinforcing steel and $\mathrm{pH}$ of test solution on chloride threshold, Cem Concr Res (1996) 26: 545-550. https://doi.org/10.1016/0008-8846(96)00018-X

[27] A. Poursaee, Determining the appropriate scan rate to perform cyclic polarization test on the steel bars in concrete, Electrochim Acta (2010) 55: 1200-1206. https://doi.org/10.1016/j.electacta.2009.10.004

[28] N. Nakayama, A. Obuchi, Inhibitory effects of 5-aminouracil on cathodic reactions of steels in saturated $\mathrm{Ca}(\mathrm{OH})_{2}$ solutions, Corros Sci (2003) 45: 2075-2092 https://doi.org/10.1016/S0010-938X(03)00032-5

[29] B. Elsener, L. Zimmermann, D. Fluckiger, D. Burchler, H. Bohni, Chloride penetration - non destructive determination of the free chloride content in mortar and concrete, Proc RILEM Int Workshop Chloride penetration into concrete, 1997.

[30] P. Schiessl, M. Raupach, Influence of concrete composition and microclimate on the critical chloride content in concrete, Proc 3rd Int Symp Corrosion of Reinforcment in Concrete, Elsevier Applied Science, 1990, 49-58.

[31] K. Pettersson, Chloride threshold value and the corrosion rate in reinforced concrete, Proc. of the Nordic Seminar, Lund, 1995, 257266.

[32] K. Pettersson, Corrosion threshold value and corrosion rate in reinforced concrete, CBI Rep 292, Swedish Cem Concr Res Inst, 1992. 
[33] C. L. Page, P. Lambert, P. R. W. Vassie, Investigations of reinforcement corrosion. 1 . The pore electrolyte phase in chloride-contaminated concrete, Mater Struct (1991) 24: 243-252.

https://doi.org/10.1007/BF02472078

[34] P. Lambert, C. L. Page, P. R. W. Vassie, Investigations of reinforcement corrosion. 2. Electrochemical monitoring of steel in chloridecontaminated concrete, Mater Struct (1991) 24: 351-358. https://doi.org/10.1007/BF02472068

[35] H. P. Leckie, H. H. Uhlig, Environmental Factors Affecting the Critical Potential for Pitting in 18-8 Stainless Steel, J Electrochem Soc (1996) 113: 1262 . https://doi.org/10.1149/1.2423801

[36] U. M. Angst, C. Boschmann, M. Wagner, B. Elsener, Experimental Protocol to Determine the Chloride Threshold Value for Corrosion in Samples Taken from Reinforced Concrete Structures, J Vis Exp (2017) 126: 1-11. https://doi.org/10.3791/56229

[37] H. Zibara, Binding of External Chlorides by Cement Pastes, PhD thesis, Dep Build Mater, Univ Toronto, Canada, 2001.

[38] A. K. Suryavanshi, J. D. Scantlebury, S. B. Lyon, The binding of chloride ions by sulphate resistant portland cement, Cem Concr Res (1995) 25 : 581-592. https://doi.org/10.1016/0008-8846(95)00047-G

[39] Q. Yuan, C. Shi, G. De Schutter, K. Audenaert, and D. Deng, Chloride binding of cement-based materials subjected to external chloride environment - A review, Constr Build Mater (2009) 23: 1-13. https://doi.org/10.1016/j.conbuildmat.2008.02.004 